JOURNAL OF SECURITY AND SUSTAINABILITY ISSUES

ISSN 2029-7017 print/ISSN 2029-7025 online

2019 June Volume 8 Number 4

http://doi.org/10.9770/jssi.2019.8.4(13)

Scopus

\title{
ASSESSMENT OF RISKS IN CONDITIONS OF PROVISION OF SECURITY OF ECONOMIC ACTIVITIES OF ORGANIZATIONS
}

\author{
Tetiana Polozova ${ }^{1}$, Maya Cherkashina², Olena Shapoval ${ }^{3}$, Tatiana Romanchik ${ }^{4}$, \\ Alzoubi Laith Abdel Karim Mohammad ${ }^{5}$ \\ ${ }^{1 * 5}$ Kharkiv National University of Radio Electronics, Nauky Ave, 14, Kharkiv, Kharkivs'ka oblast, 61000, Ukraine; \\ ${ }^{2,3}$ National Academy of National Guard of Ukraine, Maidan Zahisnikiv of Ukraine,3, \\ Kharkiv, Kharkivs'ka oblast, 61001, Ukraine \\ ${ }^{4}$ National Technical University «Kharkiv Polytechnic Institute», Kyrpychova Str. 2, \\ Kharkiv, Kharkivska oblast, 61002, Ukraine \\ E-mail: ${ }^{1 * k o a d u e p @ g m a i l . c o m ~}$
}

Received 10 December 2018; accepted 10 April 2019; published 30 June 2019

\begin{abstract}
The study of the evolution of the economic security of the business entity has shown that at the present stage of economic development it is important to consider the factors of influence on economic security, in particular: the effectiveness of management, personnel and financial safety, a strategic approach to the functioning of the communication system of protection, taking into account the evolution of security and active search for innovative modern domains of development of industrial organizations and increase of the responsibility of performers for the consequences of their work. This allows to reduce the risk of loss of economic safety of the business entity. It was argued that innovative conceptualization of risk as a probable threat of losses lies within the scope of activity of managers of various units and has features of probable economic and objective-subjective nature, as well as a wide range of variability of the impact on the issues of economic safety and is conditioned by the dynamic development of important societal significant economic processes at the global and national levels, which ultimately contributes to enhancement of the organization's competitive advantages.
\end{abstract}

Keywords: risk management, economic safety, mechanism of minimization, event occurrence probability, financial position

Reference to this paper should be made as follows: Polozova, T.; Cherkashina, M.; Shapoval, O.; Romanchik, T.; Mohammad, A.L.A.K. 2019. Assessment of risks in conditions of provision of security of economic activities of organizations, Journal of Security and Sustainability Issues 8(4): 705-712. http://doi.org/10.9770/jssi.2019.8.4(13)

JEL Classifications: F52, O39

\section{Introduction}

The treats to the safety of an industrial organization are characterized by significant changes in the external environment, which increase the probability of untimely fulfillment of obligations assumed by the subject of economic activity. At the same time, threats of this kind may have the character of universality (while generating risks of reduced profitability and unjustified increase in production costs) and specificity.

Undeniably, the risk relates to significant factors in the occurrence of profits, because of this, the receipt of a significant amount of profits is associated with differentiated risk management. Therefore, each manufacturer should chose between the possibility to get significantly higher profits from operations in the plain of risk (with the probability of loss of not only the profit, but the capital involved also) and significantly lower profitability as a result of the implementation of risk-free projects. 
The entrepreneurship is accompanied by a range of diverse risks that differ in place of appearance, level of influence, possible consequences, complex of external and internal factors that influence the intensity of their manifestation. An essential part of the analysis, assessment of risk management is their detailed classification, which provides a generalization of a number of risks based on the characteristics and factors that allow to group risks.

The science literature contains the significant number of different signs of risks and their types, which evidences that scientists have no unanimity in approaches to this issue (Hilorme, T., Nazarenko Inna, Okulicz-Kozaryn, W., Getman, O. \& Drobyazko, S. (2018), Tetiana, H., Chorna M., Karpenko L., Milyavskiy M. \& Drobyazko S. (2018); Havierniková, K., Kordoš, M. (2019); Arribas, I., Espinós-Vañó, M. D., García, F., Tamosiuniene, R. (2019); Vorotnikov, I.L., Sukhanova, I.F., Lyavina, M.Y., Glukhova, M.I., Petrov, K.A. (2019); Korauš, A., Gombár, M., Kelemen, P., Backa, S. (2019)).

\section{Literature Survey}

Typically, the external risks of business activities not directly related to the business of manufacturers or their business partners, and caused significant changes in the external environment (Florio, C., \& Leoni, G. (2017)). First of all, it concerns the activities at the international level, current competition in the market, significant exacerbation of the manifestations of the economic crisis in the country, available situation in the financial and credit market, and legislation in the tax area (Brustbauer, J. (2016)), consequences of natural disasters, wars, general state of industrial organizations, etc. Instead, internal risks of entrepreneurial activity are represented by the risks that arise from the operation of the manufacturer itself, its managers and counterparties (Oliva, F. L. (2016)).

In general, risk management can be provided in the form of a set of methods, techniques and necessary steps that will largely predict the likelihood of occurrence of risky events and take timely effective measures to prevent or minimize their negative outcomes (Choi, Y., Ye, X. , Zhao, L., \& Luo, A. C. (2016)).

There is an alternative interpretation of this definition, in which risk management is a certain process of identification, research and reduction, based on the means of effective control, or by implementing measures that can reduce the negative impact of risks in the manufacturing sector (Drobyazko, S. (2018a), Drobyazko, S. $(2018 b))$.

In accordance with the international standard FERMA, risk management is a process by which the entity fully investigates the risks of a particular type of manufacturing activity to ensure the maximum possible effect of probable steps and, as a consequence, the entire production and economic sector of the commodity producer in general (Fraser, J . R., \& Simkins, B. J. (2016); Polozova T., Musiienko V., Storozhenko O., Peresada O., Geseleva N. (2019)).

\section{Methods}

The methods used to quantify risk are universal, but they do not always allow to perform objective evaluation. The reasons for this may be lack of time, necessary information, and relevant qualifications. In addition, it should be borne in mind that there are such types of risks that require a fundamentally different approach to their assessment. Traditionally, all available risk assessment methods are summarized as follows:

- expert methods, which allow to determine the degree of risk in the absence of the necessary information for reasonable calculations or an adequate comparison, are based on the results of a survey of highly skilled specialists with further statistical and mathematical generalization of the results;

- the economic-statistical group includes methods used only if there is a significant amount of statistical data for calculation of a reliable quantitative value of risk level. In this case, the mean square deviation, $\beta$-coefficient, coefficient of variation and others are determined;

- calculation-analytical methods aimed at calculation a relatively precise quantitative risk indicator, based on the internal information base of the entity directly (usually used to assess the risk associated with insolvency 
and the lack of financial stability);

- identical methods allow to assess the degree of risk for specific transactions on the basis of comparison with the same ones, that is, repeated operations. Typically, comparisons take both their own and borrowed experience of performance of such operations.

The most common and, to some extent, universal methods include: cost-benefit analysis, analytical, statistical, expert evaluation, etc.

\section{Results}

Risk qualification according to the specified categories is determined by the probability of an occurrence and the amount of losses that may arise in a particular situation. Losses from catastrophic risks are usually the largest one, and they are the smallest, usually, from minimal risks. However, such a type of risks as catastrophic ones occurs quite rarely compared to the average or the minimum risks. It is advisable to provide a set of possible risks in the form of a certain hierarchy, which is based on minimal risks, and the highest manifestation is catastrophic risks (Table 1).

Table 1. Hierarchical levels of risk

\begin{tabular}{|c|c|c|c|c|}
\hline Differentiation & Risk level & $\begin{array}{l}\text { Probability of } \\
\text { occurrence, } \%\end{array}$ & $\begin{array}{l}\text { Losses relative to the } \\
\text { forecasted level, } \%\end{array}$ & $\begin{array}{l}\text { Negative risk manifestation } \\
\text { in the field of finance }\end{array}$ \\
\hline \multirow{2}{*}{ Low } & minimal & $0-5$ & $0-10$ & \multirow{2}{*}{ Temporary financial difficulties } \\
\hline & optimal & $5-15$ & $10-15$ & \\
\hline \multirow{2}{*}{ Moderate } & permissible & $15-25$ & $15-25$ & Temporary weakening of competitiveness \\
\hline & medium & $25-50$ & $25-50$ & \multirow{2}{*}{ Financial stagnation } \\
\hline \multirow{3}{*}{ Complete } & maximum & $50-70$ & $50-70$ & \\
\hline & critical & $70-90$ & $70-90$ & Financial instability \\
\hline & catastrophic & $90-100$ & $90-100$ & Bankruptcy \\
\hline
\end{tabular}

Of course, the priority area of activity of the overwhelming majority of manufacturers is the manufacture of commodity products or services. However, it is inextricably linked with financial activities, which serves as a means of ensuring the normal livelihoods of the industrial organization and improving its performance. All risks arising from such activities are distinguished in the group, the so-called financial risks, which have the most significant consequences in the general range of risks of the business entity. Given this, their differentiation deserves a special attention. Financial risks in the broadest sense are those business risks that are characterized by the probability of loss of available financial resources, and in somewhat narrow sense, the likelihood of financial losses due to operating activities in the financial and credit and stock markets.

At the same time, the financial risks of the manufacturer vary greatly, and it is expedient to classify them according to the characteristic features in order to effectively manage them.

In the process of analysis of the peculiarities of risks, it is appropriate to consider their non-intersecting varieties, in order to prevent double counting. However, in this case there are certain issues that require a timely solution: the same factors can influence the positive and negative dynamics of various risks;

risks that have a certain affinity and peculiarities of the risks of other varieties may at the same time be components of other groups, that is, such risks, which differ in the level of influence, can be attributed to certain economic risks, or risks identified by forms of manifestation can be attributed to the risk of public level;

One and the same kind of risk, given different conditions, can be attributed to both external and domestic ones, in particular, the risk of investment from their own sources (depreciation, profit, etc.), since the accounting government policy is based on unified approaches, however the regulatory framework provides the right to manufacturers to a certain autonomy (Stoian O., Polozova T., Didenko E., Storozhenko O., Moskvichova O. (2018)). 
The study of risks in their totality and individually allows them to establish their hierarchy, to form scenarios of probable development of events in a clearly defined situation, draw up a forecast risk map, and establish limits of stability of the management system, based on simulation, as well as other types of modelling. That is, it can be stated that the risk classification is a tool of organization for risk management.

In the specific conditions of the objective manifestation of the risk and its financial, economic, moral, ethical and other types of losses, there is an urgent need for the establishment of such a mechanism, which would allow as much as possible (taking into account the objective determined by the business entity or its management) to evaluate risk in the adoption and implementation of managerial decisions. Such a mechanism includes risk management.

It is also worth to pay due attention to the specific features of risk management. First, the purpose of risk management is to timely identify the probable risks and prevent them, instead of elimination of their negative manifestations. Secondly, risk management is a complex of innovative methodological approaches and processes, the application of which is extremely important for the implementation of strategic objectives of an industrial organization (Carroll, R. (2016)).

Thirdly, risk management should be a systematic process that studies the development of a business entity in a dynamic, that is a prior level, a modern and further interconnection. Thus, it should be integrated into the general plane of corporate culture, supported by the management, and subsequently brought to the attention of each employee of the business entity as a general effective program of further development with the outline of specific tasks for the executives. Risk management as a holistic risk management system should include an effective program of modern control over the implementation of defined tasks, a comprehensive assessment of the performance of the planned activities, as well as an effective system of motivation at all levels of the organization.

At the first stage of risk management, it is expedient to analyze the production and economic environment and establish the whole range of risks, outlining their sources, as well as objects. First of all, one should identify the most probable and dangerous risks, and then move to less probable, creating a portfolio of identified risks. In general, this is a rather difficult process, for which high professionalism, proper knowledge of the characteristics of economic, organizational, technological and technical processes is important.

The investigation of the level of entrepreneurial risk is the most responsible and rather complicated stage of the existing management process, the professionalism of which is largely dependent on the effectiveness of risk management in general. It includes not only quantitative but also qualitative risk assessment (Mun, J. (2017)).

So, based on the study of risk, you can make a presentation of the likely risk manifestations, the likelihood of their occurrence and results. Based on the comparison of the risk indicators obtained with a maximum possible one, a risk management strategy can be formed, on the basis of which measures are developed to prevent or minimize the risk (Gatzert, N., \& Schmit, J. (2016); Masood, O.; Tvaronavičienė, M.; Javaria, K. (2019)). That is, there is a certain selection process among alternative risk management methods.

After choosing the risk management methodology, the risk owners formulate the final steps to timely inform about the possibility of occurrence of a risk event and apply the chosen method of management. The existing risk management system should be sufficiently significant in assessment of the performance of the measures taken to minimize risks (Zhao, X., \& Singhaputtangkul, N. (2016)).

At the stage of impact assessment and their correction there is a set of performance indicators based on the level of neutralization of probable losses, the effectiveness and necessity of measures (proportionality of available costs associated with the regulation of risk, to the amount of probable losses), the amount of total risk of production and economic activity an industrial organization based on the steps taken to improve it (Dalevska, N.; Khobta, V.; Kwilinski, A.; Kravchenko, S. (2019)). 
The obligatory part of the risk management activity should be the organization and implementation of measures for the implementation of the planned program of actions on risk management, i.e. the determination of reasonable steps, optimal scales and possible sources of their financial support, delegation of authority to specific managers and rational deadlines of execution. During the risk management process, it is necessary to monitor the implementation of risk management measures (Bromiley, P., Rau, D., \& McShane, M. K. (2016)).

In the course of processing of available data, one should determine the risk factors, the extent of which can have a significant impact on all the most important areas of the business entity, the failure of which in normal operation can cause significant financial harm. The most significant spheres of operation include the production of commodity products, sale, storage of basic and circulating assets and human resources (Choi, T. M., Chan, H. K., \& Yue, X. (2017)).

Any management solution is accompanied by a certain level of risk, which is why it is very important to promptly investigate and objectively assess the probable amounts of risk posing a threat to the business entity in the case of choosing a particular area of action. The main objective of risk research is to form and provide the prospective partners with the necessary array of information to decide on the feasibility of be engaged in work on the project and development of a set of measures to protect against potential financial losses.

The objective and qualitative analysis belongs to the most complex tasks of economic riskology. This work requires the use of fundamental knowledge not only in the field of the theory of economics, finance, business, but also many basic skills, which the competitive specialist at the domestic labour market must possess. It is also important to have a set of necessary skills and some practical experience in the field of economic activity. The main tasks in carrying out qualitative risk research include identification of probable varieties of risk, assessment of the degree of their threat, and the identification of factors that form the risk factors (Singhal, A., \& Ou, X. (2017)).

A significant addition to the objective analysis may be the quantitative expression of the business risk. Risk analysis by means of quantitative expression represents the numerical value of certain types of risks, as well as the existing aggregate risk of the whole area of production and economic activity. Quantitative reflection of the degree of risk is usually not characterized unambiguously. Given the probable risk assessment method used, its value may vary. In order to quantify the degree of risk, the various subjective purely intuitive methods are used. Today, Ukrainian executives, as a rule, often use intuitive methods, relying on the well-deserved authority or the accumulated experience of successful predecessors. Only a part of senior managers can give proper assessment of risk based on the application of economic and mathematical models.

The content of the method of study of expediency of costs is that the costs of a certain area of production and economic sphere, its separate components are characterized by the presence of different levels of risk.

In particular, the level of risk in terms of costs associated primarily with the acquisition of raw materials is higher than the labour costs.

The establishment of the level of risk by examining expediency is aimed at identifying probable segments of risk (Table 2). To this end, the state of each element of costs is usually divided into risk areas that form the sector of general losses, in which the clearly identified losses are less than the maximum permissible level of risk. 
Table 2. The risk limits depending on the state of crisis

\begin{tabular}{|c|c|c|c|c|c|}
\hline $\begin{array}{c}\text { Area of organization } \\
\text { activities }\end{array}$ & $\begin{array}{c}\text { Absolute } \\
\text { stability }\end{array}$ & $\begin{array}{c}\text { Normal } \\
\text { stability }\end{array}$ & $\begin{array}{c}\text { Unstable } \\
\text { state }\end{array}$ & $\begin{array}{c}\text { Critical } \\
\text { state }\end{array}$ & $\begin{array}{c}\text { Sector } \\
\text { Sectors of risk }\end{array}$ \\
\hline $\begin{array}{c}\text { Risk free } \\
\text { sector } \\
\text { of minimal } \\
\text { risk }\end{array}$ & $\begin{array}{c}\text { Sector } \\
\text { of increased } \\
\text { risk }\end{array}$ & $\begin{array}{c}\text { Sector of } \\
\text { unacceptable } \\
\text { risk }\end{array}$ \\
\hline $\begin{array}{c}\text { Maximum } \\
\text { possible } \\
\text { losses }\end{array}$ & $\begin{array}{c}\text { Complete } \\
\text { absence } \\
\text { of losses }\end{array}$ & profit & Gross \\
profit & $\begin{array}{c}\text { Revenue from } \\
\text { sales and property }\end{array}$ \\
\hline $\begin{array}{c}\text { Level } \\
\text { of risk }\end{array}$ & 0 & $0-25$ & $25-50$ & $50-75$ & $75-100$ \\
\hline
\end{tabular}

Significant advantages of this method can be attributed to the fact that having information on the item of expenses with the maximum allowable risk, it is possible to determine the areas of its reduction. In particular, having information that the risk relates to the rental of a vehicle, it is possible to review the issue of terms of transportation of material assets.

The main disadvantage of the method is that an entity does not properly assess potential sources of risk, instead it treats the risk as a constant, without taking into account its elements.

However, the method of expert evaluations is somewhat subjective compared to alternative ways. Such subjectivity arises as a team of experts dealing with risk assessment expresses its own subjective perception of the previous state and development prospects.

As a rule, this method is used in the case of insufficient amount of information or in case of determination of the degree of risk of this area of production and economic activity, which has no analogues, which does not allow to analyze the preliminary data.

In generalized form, the role of this method is determined by the fact that the business entity distinguishes a certain number of risks and explores how they are able to influence its production and economic activity. Such an approach is limited to the determination of the score criterion for the probability of occurrence of the risk of one or another type, as well as the level of its impact on the activities of an industrial organization.

In the conditions of the stability of the internal and external environment of the entity, the required array of data on the state of certain operations (revenue and losses), processes, vectors of economic recovery, the mechanisms of statistical approach to risk assessment are used. This approach is based on the theory of the probability of a certain distribution of random variables.

With a sufficient amount of information on the availability of certain types of risk in previous periods, the manufacturer is able to assess the likelihood of their occurrence in the future.

The analytical method for risk analysis is a set of statistical indicators based on the preliminary selection of the main characteristics with further study of the impact of risk factors on them by experts. It is a combination of statistical calculation and principles in relation to the expert analysis.

The strengths of the analytical method are the combination of factor analysis of indicators that significantly affect the risk, and the establishment of appropriate methods for reduction of the degree of its manifestation. The risk study, being based on data on the financial position of an entity, is the most popular method of relative risk assessment for a senior manager and its business partners, as the main sources of information required are the financial statements of the manufacturer, primarily the balance sheet and the report on financial results.

The financial condition of an entity can be defined as a complex category, which is determined by a system of balanced absolute and relative values that show not only the availability but also the optimal placement and effective use of financial resources of the industrial organization. 
The study of these indicators makes it possible to assess the current financial stability of the business entity.

The identity method is used when other known risk assessment methods are unacceptable. The specificity of this method is determined by the fact that in the process of studying the level of risk of a particular vector of the entrepreneurial sphere, the information should be used on the development of such areas in the past.

The objective complexity of application of this method of assessment of the level of risk is due to the fact that the indicators of previous periods need to be applied at the moment, not considering that any vector of entrepreneurial activity is in constant development.

After study and evaluation of identified risks, it is quite logical to choose the ways to reduce the risk, that is, minimization of the probable losses during those or other operations.

\section{Discussion}

The international experience contains a large number of diverse and original methods for reduction of risk, the most popular of which are: insurance; risk transfer; diversification; obtaining an additional array of relevant information; business planning; limitation; compliance with the quality standards of the manufactured products; thorough check of business partners; ensuring the security of commercial activity of an industrial organization; qualified personnel selection for a business entity.

The main approaches to risk reduction and their content are presented in Table 3.

Table 3. Mechanisms for minimization of risks

\begin{tabular}{|c|c|}
\hline The mechanism of minimization & The essence of the method \\
\hline $\begin{array}{l}\text { Prevention is the most effective } \\
\text { method }\end{array}$ & $\begin{array}{l}\text { refusal to carry out certain business operations, the degree of risk on which is quite significant } \\
\text { and not fully consistent with the financial policies of the business entity; } \\
\text { reduction of the share of borrowed funds in the production and economic circulation allows } \\
\text { to prevent loss of financial stability; the increase of the liquidity of available assets through } \\
\text { increase of the circulating assets in the general array makes it possible to prevent the risk of } \\
\text { insolvency. }\end{array}$ \\
\hline $\begin{array}{l}\text { The minimization of risks - is used } \\
\text { when it is impossible to avoid them }\end{array}$ & $\begin{array}{l}\text { receipt of guarantees from the consumer regarding timely payment of the debt; } \\
\text { narrowing the list of unreasonable force majeure situations in contracts with counterparties, } \\
\text { which will make it possible to increase financial responsibility for the unfair performance of } \\
\text { contractual obligations, that is, to reduce the commercial risk. }\end{array}$ \\
\hline $\begin{array}{l}\text { Diversification of risks - allows you to } \\
\text { reduce the level of risk concentration }\end{array}$ & $\begin{array}{l}\text { diversification of the spheres of activity allows using additional opportunities for obtaining } \\
\text { revenues and profits from diverse financial and economic transactions; } \\
\text { diversification of suppliers of products involves establishing relations with many partners in } \\
\text { order to supply the main nomenclature of goods; } \\
\text { diversification of existing goods for sale - introduction into the assortment of the industrial } \\
\text { organization of products with opposite demand within certain commodity groups, which } \\
\text { makes it possible to reduce the risk in case of worthening of the market situation in a certain } \\
\text { commodity market; } \\
\text { The diversification of deposit savings consists in placing available temporarily released cash } \\
\text { assets for deposit storage in several banks. }\end{array}$ \\
\hline $\begin{array}{l}\text { The limitation of the risks of } \\
\text { transactions that have the tendency } \\
\text { to systematically go beyond the } \\
\text { permissible risk limit; such a risk } \\
\text { is limited by the introduction of } \\
\text { appropriate financial and economic } \\
\text { standards }\end{array}$ & $\begin{array}{l}\text { the maximum possible volume of a commercial transaction aimed at the purchase of goods in } \\
\text { the case of its implementation with the same counterparty; } \\
\text { acceptable amount of borrowed funds in financial and economic circulation; } \\
\text { the maximum amount of deposit in a single commercial banking institution, etc. }\end{array}$ \\
\hline
\end{tabular}

In order to minimize risks, it is advisable for managers to develop a risk management program that combines the mechanism for the formation or adjustment of appropriate risk management procedures in an industrial organization. In order to justify the feasibility of development of a risk management program, it is necessary to 
determine the significance of internal threats to the organizations business, which is usually about $75 \%$ of the existing risks that have a significant impact on the functioning of an industrial organization.

The programs for minimization of unpredictable risks developed by the management needs to be correlated with innovative capabilities. Directly, the recovery and the process of modernization of a particular organization should be aimed at minimization of the risks of accidents, certain environmental damage, and so on.

\section{Conclusions}

The formation of a risk management program shall be carried out in two stages. The preparatory stage of the risk management program compilation includes the study of a reference and information base that is relevant to the identified problem. This allows you to approve the urgent decisions before the next - the main stage - and go directly to the development and coordination of the risk management program.

The main stage of the development of the risk management program is the synthesis of relevant information on the potential risks from which the business entity has refused the stage of pre-selection, the formation of a plan for the implementation of preventive measures and taking into account all probable risks and existing mechanisms for managing them. The risk management program should be based on key risk features and the most probable, most likely and forecasted losses.

Diagnose existing risks in several planes, which will allow you to fully characterize the overall state of threats. The environment in which there are risks is assessed first of all: natural conditions, production, socio-political situation, economic conditions, personnel, etc. The introduction of such a risk management mechanism in an industrial organization is less productive than in the case where a special department has been created in its structure that addresses issues related to threats, since the specialists of these structural units significantly reduce the sensitivity of the entity to the manifestation of the available risks.

Typically, the task of managing risks in industrial organizations is assigned to special structural units. In the event that the infrastructure of the industrial organization not provides such a unit, the management may decide to engage regular risk management specialists or external consultants. However, as experience shows, quite often the risk management functions are imposed on other structural units. Typically, these tasks can be performed by the internal audit department, controlling service, and forecasting analytical unit. In this situation, threats are diagnosed in a timely manner, and their consequences are eliminated promptly, which protects the commodity producer from the probable significant losses.

It was substantiated that risk situations are accompanied by an urgent need to choose between different variants, a polar understanding of a certain magnitude of risk by theoreticians and practitioners as a result of differences between psychological and ethical and value systems and principles. This determines the subjectivity of the vision of this category. At the same time, the risk is an objective factor, due to the fact that it is inherent in most of the existing production and economic operations, and functions not being based on the will or consciousness of the individual, and neglect or recognition of its existence by an individual. So, one can agree that the risk itself has both a subjective and objective nature.

In the course of the study, it was substantiated that socio-economic, organizational and legal factors influence the formation of economic security of an economic entity. Any industrial organization is characterized by certain features in the area of legal relations and the establishment of its own business security system. In view of the imperfection of the current legislation, as well as the level of scientific and practical experience in substantiation and creation of an effective system of economic protection of the manufacturer, it is advisable to draw attention to the achievements of the international community in this area.

Taking into account world experience it can be stated that in developed countries, as a rule, there is a coexistence of two basic systems of formation of economic protection of manufacturers: the systems of protection at the state 
level, which are responsible for national security, with the spread of their influence on state and private business entities in the plane of the current normative field; private entities that form their own economic security services or use detective-security agencies develop their own systems of necessary mode of confidentiality and security. Only the combination of the capabilities of both systems can guarantee the economic security of business interests, in particular, and in general the interests of the state, by ensuring business stability, preventing the likelihood of bankruptcy, compensating for losses caused by natural disasters or unfair competition, industrial espionage or other illegal actions.

\section{References}

Arribas, I., Espinós-Vañó, M. D., García, F., Tamosiuniene, R. (2019). Negative screening and sustainable portfolio diversification, Entrepreneurship and Sustainability Issues 6(4): 1566-1586. https://doi.org/10.9770/jesi.2019.6.4(2)

Bromiley, P., Rau, D., \& McShane, M. K. (2016). Can strategic risk management contribute to enterprise risk management? A strategic management perspective. A Strategic Management Perspective (October 20, 2014). Forthcoming: Bromiley, P., Rau, D., and Mcshane, M, 140-156. URL: https://papers.ssrn.com/sol3/papers.cfm?abstract_id=2512477

Brustbauer, J. (2016). Enterprise risk management in SMEs: Towards a structural model. International Small Business Journal, 34(1), 70-85. URL: https://journals.sagepub.com/doi/abs/10.1177/0266242614542853

Carroll, R. (2016). Identifying risks in the realm of enterprise risk management. Journal of healthcare risk management, 35(3), 24-30. URL: https://onlinelibrary.wiley.com/doi/abs/10.1002/jhrm.21206

Choi, T. M., Chan, H. K., \& Yue, X. (2017). Recent development in big data analytics for business operations and risk management. IEEE transactions on cybernetics, 47(1), 81-92. URL: https://ieeexplore.ieee.org/abstract/document/7378465

Choi, Y., Ye, X., Zhao, L., \& Luo, A. C. (2016). Optimizing enterprise risk management: a literature review and critical analysis of the work of Wu and Olson. Annals of Operations Research, 237(1-2), 281-300. URL: https://link.springer.com/article/10.1007/s10479-0151789-5

Drobyazko, S. (2018). Accounting management of enterprises' own of in the conditions of legislative changes. Economics and Finance, 10, 4-11. URL: http://ecofin.at.ua/maket_ehkonomika_i_finansy_06_2018.pdf

Drobyazko, S. (2018). Features of tourism services accounting structuring in the information-oriented society. Economics and Finance, Volume, 6, 44-49. URL: http://ecofin.at.ua/maket_ehkonomika_i_finansy_10_2018.pdf

Florio, C., \& Leoni, G. (2017). Enterprise risk management and firm performance: The Italian case. The British Accounting Review, 49(1), 56-74. URL: https://www.sciencedirect.com/science/article/abs/pii/S0890838916300221

Fraser, J. R., \& Simkins, B. J. (2016). The challenges of and solutions for implementing enterprise risk management. Business Horizons, 59(6), 689-698. URL: https://www.sciencedirect.com/science/article/pii/S000768131630057X

Gatzert, N., \& Schmit, J. (2016). Supporting strategic success through enterprise-wide reputation risk management. The Journal of Risk Finance, 17(1), 26-45. URL: https://www.emeraldinsight.com/doi/abs/10.1108/JRF-09-2015-0083

Dalevska, N.; Khobta, V.; Kwilinski, A.; Kravchenko, S. (2019). A model for estimating social and economic indicators of sustainable development, Entrepreneurship and Sustainability Issues 6(4): 1839-1860. http://doi.org/10.9770/jesi.2019.6.4(21)

Havierniková, K., Kordoš, M. (2019). Selected risks perceived by SMEs related to sustainable entrepreneurship in case of engagement into cluster cooperation, Entrepreneurship and Sustainability Issues 6(4): 1680-1693. http://doi.org/10.9770/jesi.2019.6.4(9)

Hilorme, T., Nazarenko Inna, Okulicz-Kozaryn, W., Getman, O. \& Drobyazko, S. (2018). Innovative model of economic behavior of agents in the sphere of energy conservation. Academy of Entrepreneurship Journal, Volume 24, Issue 3 URL: https://www.abacademies. org/journals/month-september-year-2018-vol-24-issue-3-journal-aej-past-issue.html

Korauš, A., Gombár, M., Kelemen, P., Backa, S. (2019). Using quantitative methods to identify insecurity due to unusual business operations, Entrepreneurship and Sustainability Issues 6(3): 1101-1012. http://doi.org/10.9770/jesi.2019.6.3(3)

Masood, O., Tvaronavičienė, M., Javaria, K. (2019). Impact of oil prices on stock return: evidence from G7 countries, Insights into Regional Development 1(2): 129-137. https://doi.org/10.9770/ird.2019.1.2(4)

Mun, J. (2017). U.S. Patent No. 9,811,794. Washington, DC: U.S. Patent and Trademark Office. URL: https://patents.google.com/ patent/US9811794B2/en 
Polozova T., Musiienko V., Storozhenko O., Peresada O., Geseleva N. (2019) Modeling of energy-saving processes in the context of energy safety and security. Journal of security and sustainability issues 8(3): 387-397. http://doi.org/10,9770 / jssi.2019.8.3 (8)

Singhal, A., \& Ou, X. (2017). Security risk analysis of enterprise networks using probabilistic attack graphs. In Network Security Metrics (pp. 53-73). Springer, Cham. URL: https://link.springer.com/chapter/10.1007/978-3-319-66505-4_3

Stoian, O., Polozova, T., Didenko, E., Storozhenko, O., Moskvichova, O. (2018). Strategies of interaction with a consumer within the marketing product policy, Entrepreneurship and Sustainability Issues 6 (2): 1018-1027. http://doi.org/10.9770/jesi.2019.6.2(36)

Tetiana, H., Chorna M., Karpenko L., Milyavskiy M. \& Drobyazko S. (2018). Innovative model of enterprises personnel incentives evaluation. Academy of Strategic Management Journal. Volume 17, Issue 3, 2018 URL: https://www.abacademies.org/journals/monthjune-year-2018-vol-17-issue-3-journal-asmj-past-issue.html

Tetiana, H., Karpenko, L., Fedoruk, O., Shevchenko, I., \& Drobyazko, S. (2018). Innovative methods of performance evaluation of energy efficiency project. Academy of Strategic Management Journal, 17(2), 112-110. URL: ,

Vorotnikov, I.L., Sukhanova, I.F., Lyavina, M.Y., Glukhova, M.I., Petrov, K.A. (2019). Economic sanctions and import substitution, Entrepreneurship and Sustainability Issues 6(4): 1872-1883. http://doi.org/10.9770/jesi.2019.6.4(23)

Zhao, X., \& Singhaputtangkul, N. (2016). Effects of firm characteristics on enterprise risk management: Case study of Chinese construction firms operating in Singapore. Journal of Management in Engineering, 32(4), 05016008. URL: https://ascelibrary.org/doi/ abs/10.1061/(ASCE)ME.1943-5479.0000434

Short biographical note about the contributors at the end of the article:

Tetiana POLOzOVA, Doctor of Economic Sciences, Head of Department of Economic Cybernetics and Management of Economic Security, Kharkov National University of Radio Electronics, Ukraine

ORCID ID: orcid.org/0000-0001-9956-8816

Maya CHERKASHINA, Candidate of Economic Sciences, Head of the Department of Management and Military Economy, National Academy of National Guard of Ukraine, Kharkiv, Ukraine

ORCID ID: orcid.org/0000-0001-9543-5047

Olena SHAPOVAL, Candidate of Pedagogical Sciences, Associate Professor of the Department of Management and Military Economy, National Academy of National Guard of Ukraine, Kharkiv, Ukraine

ORCID ID: orcid.org/0000-0002-1939-9811

Tatiana ROMANCHIK, Candidate of Economic Sciences, Associate Professor of Department of Economics and Marketing, National Technical University «Kharkiv Polytechnic Institute», Ukraine

ORCID: ID: orcid.org/0000-0002-2065-2415

Alzoubi Laith Abdel Karim Mohammad, PhD Student of Department of Economic Cybernetics and Management of Economic Security, Kharkov National University of Radio Electronics, Ukraine

ORCID ID: https://orcid.org/0000-0002-1240-8869

Register for an ORCID ID:

https://orcid.org/register

This work is licensed under the Creative Commons Attribution International License (CC BY).

http://creativecommons.org/licenses/by/4.0/ 